ECOTOX - Brazil

\title{
Sub-chronic and Trophic Effects of TBT and DBT in American plaice (Hippoglossoides platessoides)
}

\author{
C. A. Oliveira Ribeiro ${ }^{1 *}$, F. Filipak Neto ${ }^{1}$, A. Siah ${ }^{2}$, E. Pelletier ${ }^{2}$ \\ ${ }^{1}$ Departamento de Biologia Celular, Universidade Federal do Paraná, CP 19031, CEP 81.531-990, Curitiba - PR, Brasil \\ ${ }^{2}$ Institut des Sciences de la Mer de Rimouski - ISMER, 310, allée des Ursulines - Rimosuki (Québec) Canada G5L 31
}

(Received August 15, 2008; Accepted June 30, 2009)

\begin{abstract}
Tributyltin (TBT) has been used as antifouling in ship paints and directly released into marine environment for many decades. TBT and its metabolites dibutyltin (DBT) and monobutyltin (MBT) are known to cause multiple toxic stresses to aquatic organisms at cellular and ecosystem levels. In the current study, the marine fish American plaice (Hippoglossoides platessoides) was used to investigate TBT and DBT bioaccumulation and to evaluate its morphological effects after trophic and sub-chronic exposure doses. Four groups of seven male and female mature fish were separated in four tanks (control, TBT, TBT water quality control and DBT groups), and exposed by food to four and eight doses of TBT and DBT ( $30 \mathrm{ng} \mathrm{g}^{-1}$ each three days, corresponding respectively to 12 and 24 days of exposure). After four and eight doses, three animals were anesthetized from each tank and liver, spleen and posterior kidney were sampled for histopathological studies and muscle for chemical analysis. Chemical results showed that only TBT was bioaccumulated in muscle with a decreasing rate after 24 days. Necrotic areas were observed in liver and vacuolated cells and cellular deposit were found within renal tubules for both TBT and DBT exposed groups although DBT and MBT were not detected in fish muscle.
\end{abstract}

Keywords: bioaccumulation, bioassay, DBT, Hippoglossoides platessoides, TBT, trophic exposure.

\section{RESUMO}

\section{Bioacumulação e efeito trófico e subcrônico do TBT e DBT em linguado (Hipposglossoides platessoides)}

O tributilestanho (TBT) tem sido utilizado como antiaderente em pinturas de navio e diretamente liberado para os ambientes aquáticos por décadas. O TBT e seus metabólitos dibutilestanho (DBT) e monobutilestantho (MBT) podem causar danos na saúde de organismos aquáticos devido às suas propriedades tóxicas. No presente estudo, o peixe marinho American plaice (Hippoglossoides platessoides) foi utilizado para investigar a bioacumulação e os efeitos morfológicos do TBT e DBT após exposição trófica e subcrônica. Quatro grupos de sete indivíduos adultos entre fêmeas e machos foram separados em quatro tanques (controle, TBT, controle da qualidade da água e DBT), e quatro e oito doses de TBT e DBT foram testadas (30 $\mathrm{ng} \mathrm{g}^{-1}$ cada três dias, correspondendo respectivamente a 12 e 24 dias de exposição). Após quatro e oito doses três animais foram anestesiados de cada tanque e o fígado, baço e o rim posterior foram amostrado para estudos de histopatologia e o músculo para análises químicas. Os resultados mostraram que somente o TBT foi bioacumulado no músculo decrescendo sua taxa após 24 dias. Áreas necróticas foram observadas em fígado e células vacuolizadas e depósitos celulares foram encontrados dentro dos túbulos renais. Os presentes danos tem sido também descritos para outras espécies de peixes devido a exposição ao TBT.

Palavras-chave: bioacumulação, bioensaios, DBT, TBT, Hippoglossoides platessoides, exposição trófica. 


\section{INTRODUCTION}

The IMO International Convention on the Control of Harmful Anti-Fouling Systems (2001) (Adoption: 5 October 2001; Entry in force: 17 September 2008) prohibits the use of harmful organotins in anti-fouling paints used on ships. According to the Convention this regulation applies to all ships (except fixed and floating platforms, floating storage units (FSUs), and floating production storage and off-loading units (FPSOs) that have been constructed prior to 1 January 2003 and that have not been in dry-dock on or after 1 January 2003.

However, the use of butyltins for decades contaminated most marine aquatic ecosystems in different coastal regions around the world (International Marine Coatings, 2008). Tributyltin (TBT) is a compound added to antifouling paints widely used in the past to protect small and large ships from fooling and constituted the main source of organotins detected in estuarine ecosystems (Fent, 1996). High levels of TBT have been detected in several marinas and harbors (Pickston, 1988; Alzieu et al., 1989; Daly; Fabris, 1993), where damages to aquatic organisms have been described (Gibbs et al, 1988; Byrne et al, 1989; Ellis; Pattisina, 1990; Kingtong et al., 2007), but the toxic mechanisms have not been completely elucidated. Oliveira Ribeiro et al. (2000) described the morphological effects of TBT in tropical fish Astyanax $s p$. and more recently in northern fish Salvelinus alpinus (Oliveira Ribeiro et al., 2007) after intraperitoneal injection, a practical method to observe direct damages to cells and tissues but considered environmentally unrealistic. The histopathological changes in fish depend on the chemical concentration, exposure time, uptake routes, species and other environmental features (Oliveira Ribeiro et al., 2005; Valdez Domingos et al., 2007). In addition, fish have been shown to bioaccumulate organotins from food chain (Martin et al., 1989; Schwaiger et al., 1992), but sediments and suspended particles might be the main sources of organotin to biota (Tanabe et al., 1994). In this short study, the marine fish American plaice (Hippoglossoides platessoides) has been submitted to a laboratory sub-chronic exposure by trophic route to investigate the uptake and bioaccumulation of TBT and its metabolites dibutyltin (DBT) in muscle, and to evaluate the histological damages in liver, spleen and posterior kidney.

\section{MATERIAL AND METHODS}

The American plaice Hipoglossoides platessoides is a high valued commercial demersal species distributed in the eastern and western North Atlantic Ocean. This bottom fish species fed mainly invertebrates and small fish (Fishbase, 2008). Twenty-eigth (28) male and female mature fish were acclimatized for 20 days under experimental conditions $(12 \mathrm{~h}$ light $/ 12 \mathrm{~h}$ dark) and constant flow water in tanks of 80 liters. For the experimental design, the group was randomly separated in four groups (seven individuals each), then three groups were maintained in the same tank separated by nets and one, the control group (mean fish weight $=34.86 \pm 6.6 \mathrm{~g}$ ), was isolated in another tank. The three groups in the same tank were used respectively as TBT (48.04 $\pm 9.31 \mathrm{~g})$, TBT water quality control
$(40.34 \pm 14.14 \mathrm{~g})$ and DBT $(49.48 \pm 16.4 \mathrm{~g})$ groups. The doses $\left(\mathrm{TBT}=30 \mathrm{ng} \mathrm{g}^{-1} \pm 0.0038\right.$ and $\mathrm{DBT}=30 \mathrm{ng} \mathrm{g}^{-1} \pm 0.0068$ ) were administrated in food pellets according to Oliveira Ribeiro et al. (1999) after each three-day period during 12 to 24 days (Figure 1). The TBT water quality control group was used to control the excretion of organotins from the first group (TBT group) that could compromise the DBT group. After four and eight doses, three fish were anesthetized (MS222, 0.2\%) and muscle samples were dissected and frozen for chemical analysis. Liver, spleen and kidney samples were collected for a preliminary histological study ( $\mathrm{n}=3 \mathrm{fish} /$ treatment/time point), preserved in fixative solution ALFAC (ethanol 80\%, formaldehyde 6\% and acetic glacial acid 5\%) for $16 \mathrm{~h}$, dehydrated in ethanol and embedded in Paraplast Plus resin (Sigma Co.). Sections ( $5 \mu \mathrm{m}$ thick) were stained in haematoxylin and eosin (HE) and examined by light microscopy. Toxicopathic lesions were classified according to the diagnostic criteria of Boorman et al. (1997). For electronic microscopy evaluation, a separate sample of liver tissue was fixed in $2.5 \%$ glutaraldehyde and $1.8 \%$ paraformaldehyde in $0.1 \mathrm{M}$ sodium cacodylate buffer ( $\mathrm{pH} 7.2$ ), post fixed in $1 \%$ osmium tetroxide, dehydrated in ethanol, propylene oxide, and embedded in PoliEmbed 812 plastic resin (EMS). Semi-thin sections were stained with toluidine blue and the ultra-thin sections were contrasted by uranil acetate $(5 \%)$ and lead citrate, and evaluated using a JEOLTEM 1200 EXII transmission electron microscope.

Butyltin compounds have been analyzed by gas chromatography coupled to mass spectrometry (GC/MS) following a method developed in our laboratory (Viglino et al., 2005). Briefly, freeze-dried tissue $(0.4 \mathrm{~g})$ was digested in tetramethyl ammonium hydroxide (TMAH); butyltins were then extracted with toluene and derivatized with sodium tetraethyl borate before injection in GC/MS. The recovery of butyltin species was determinated by successive extractions $(n=6)$ of standard mussel tissues (CRM 477) and was $92 \pm 11 \%$ for MBT, $74 \pm$ $11 \%$ for DBT and $79 \% \pm 12 \%$ for TBT. The detection limit was the same for each butyltin species and estimated to $0.75 \mathrm{ng} \mathrm{g}^{-1}$ dry weight. Butyltin concentrations were not corrected for the recovery yield and are reported as tin (ng $\mathrm{Sn} / \mathrm{g}$ of dry weight.)

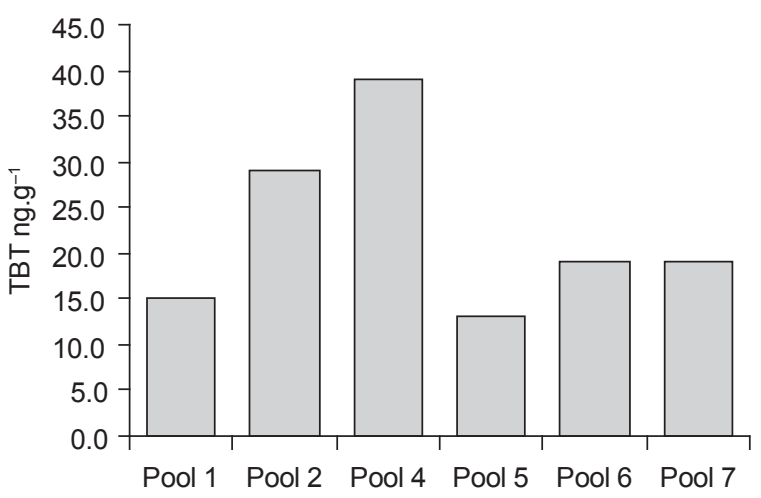

Figure 1 - Experimental design. Four tanks with approximately 80 liters each were maintained with a constant seawater flow. The tested groups (seven individuals each) were separated by nets in the same tank. 


\section{RESULTS}

Chemical analysis showed bioaccumulation of TBT in fish was higher after four (4) doses and decreased after eight (8) doses indicating an adaptation of fish to butyltin exposure and an increase of their excretion capability after a few weeks (Table 1). Also it was observed that metabolites (DBT and MBT) were not found in muscle of individuals exposed to TBT group after four and eight doses, showing that these compounds are not accumulated in this tissue. Also neither TBT nor DBT were detected in muscle of individuals used as TBT water quality control and no tissues damages were observed (Tables 1 and 2).

The tissular organization of liver, spleen and posterior kidney of the American plaice (Hippoglossoides platessoides) is similar to other species of teleosts. The presence of histopathological lesions showed that TBT and DBT are toxic to this species after a trophic exposure, despite of low doses administrated (Table 2). Liver and posterior kidneys were affected and important lesions as necrosis incidence appeared in the majority of individuals mainly after 8 doses.

Necrotic areas were found in both target organs, liver and posterior kidney, from TBT and DBT groups (Figure 2 and Table 2). A low occurence of this lesion was present in individuals from TBT water quality control group, as well in control group after eight doses in kidney, but absent in liver from the control group. More lesions were observed in liver of individuals exposed to DBT after eight doses but the higher incidence in kidney was in individuals exposed to TBT (Table 2). The groups exposed to TBT and DBT presented a vase and

Table 1 - TBT bioaccumulation in muscle of Hippoglossoides platessoides after four and eight doses (trophic and subchronic exposure). The data are expressed as $\mathrm{ng} \mathrm{Sn} / \mathrm{g} \mathrm{dw}$.

\begin{tabular}{lcccc}
\hline \multicolumn{1}{c}{ Groups } & $\begin{array}{c}\text { Individuals } \\
\text { Number }\end{array}$ & $\begin{array}{c}\text { Muscle } \\
(\mathbf{g})\end{array}$ & $\begin{array}{c}\mathbf{4} \text { doses } \\
\left(\mathbf{n g ~ g}^{-1}\right)\end{array}$ & $\begin{array}{c}\mathbf{8} \text { doses } \\
\left(\mathbf{n g ~ g}^{-1}\right)\end{array}$ \\
\hline Control (Pool 1) & 3 & 0.51 & nd & nd \\
TBT (Pool 2) & 3 & 0.50 & 29.0 & 6.1 \\
TBT (Pool 3) & 3 & 0.52 & 13.0 & 5.3 \\
TBT (Pool 4) & 3 & 0.50 & 19.0 & 7.8 \\
DBT (Pool 5) & 3 & 0.50 & nd & nd \\
DBT (Pool 6) & 4 & 0.52 & nd & nd \\
\hline
\end{tabular}

nd means not detectable. sinusoids enlargement in liver after eight doses although a lower incidence was observed in individuals from all tested groups after four doses (Table 2). The highest incidence was observed in individuals exposed to TBT and DBT after eight doses. This physiological parameter is affected by residual TBT or DBT present in water from TBT group and detected in TBT water quality control group (Table 2). The incidence of vacuolated cells in epithelial tissue forming the ducts in posterior kidney was observed in individuals exposed to DBT after four and eight doses, but appeared more evident in animals exposed to eight doses. Cellular death is one of the drastic effects of organotin exposure. In the current work, the presence of cellular deposits within kidney ducts in all tested groups suggests the occurrence of necrosis in the duct epithelial tissue (Figure 2e). Despite the low occurrence in control and TBT water quality control groups after 8 doses, this kind of alterations was more frequently observed in the exposed groups to butyltins than control groups.

\section{DISCUSSION}

The absence of DBT and MBT in muscle of individuals exposed to TBT exposed group after four and eight doses is not a surprising result as DBT and MBT are relatively soluble in water and easily excreted by fish (Lee, 1991). In a comparative study using $\mathrm{BaP}$ and TBT in trout, Oliveira Ribeiro et al. (2007) showed that, despite of the severity of lesions in fish exposed to $\mathrm{BaP}$ alone, damages as necrosis in liver and kidney were also observed in individuals exposed to TBT alone. The metabolism of TBT is considered to be a detoxification process, as TBT metabolites mono- and dibutyltin have been shown to be less toxic than parent TBT (Wester and Canton, 1987). However, we found in the current work that the DBT group was highly affected after eight trophic doses, contrary to the results reported by Wester and Canton (1987) and some others. It should be mentioned that a study by St-Jean et al., (2002) on the immunotoxicity of TBT and DBT on hemocytes of blue mussel reported that in vivo hemocyte function was more affected by DBT than by TBT, providing a first indication that DBT might be more toxic than TBT at cellular level.

Zhang et al. (2008) described the occurrence of reactive oxygen species associated with TBT exposure at environmental

Table 2 - Occurrence of lesions observed in liver and kidney of Hippoglossoides platessoides after four and eight doses of TBT and DBT trophic and subchronic exposure. C - Control group, C-TBT - TBT water quality group, TBT exposed group, DBT exposed group.

\begin{tabular}{|c|c|c|c|c|c|c|c|c|}
\hline \multirow[b]{2}{*}{ Lesions } & \multicolumn{4}{|c|}{ Four Doses } & \multicolumn{4}{|c|}{ Eight Doses } \\
\hline & $\mathrm{C}$ & C-TBT & TBT & DBT & $\mathrm{C}$ & C-TBT & TBT & DBT \\
\hline \multicolumn{9}{|l|}{ Liver } \\
\hline Necrosis area & - & - & + & + & - & + & ++ & +++ \\
\hline Vase enlargement & - & + & ++ & + & - & ++ & +++ & ++ \\
\hline Sinusoid Enlargement & - & - & ++ & +++ & + & ++ & ++ & ++ \\
\hline \multicolumn{9}{|l|}{ Kidney } \\
\hline Necrosis area & - & - & ++ & ++ & + & + & +++ & ++ \\
\hline Vacuolated cells in tubules & - & - & - & + & - & + & + & ++ \\
\hline Cellular residues within tubules & - & - & ++ & + & + & + & ++ & ++ \\
\hline
\end{tabular}

(+) means the individual incidence of lesion. 

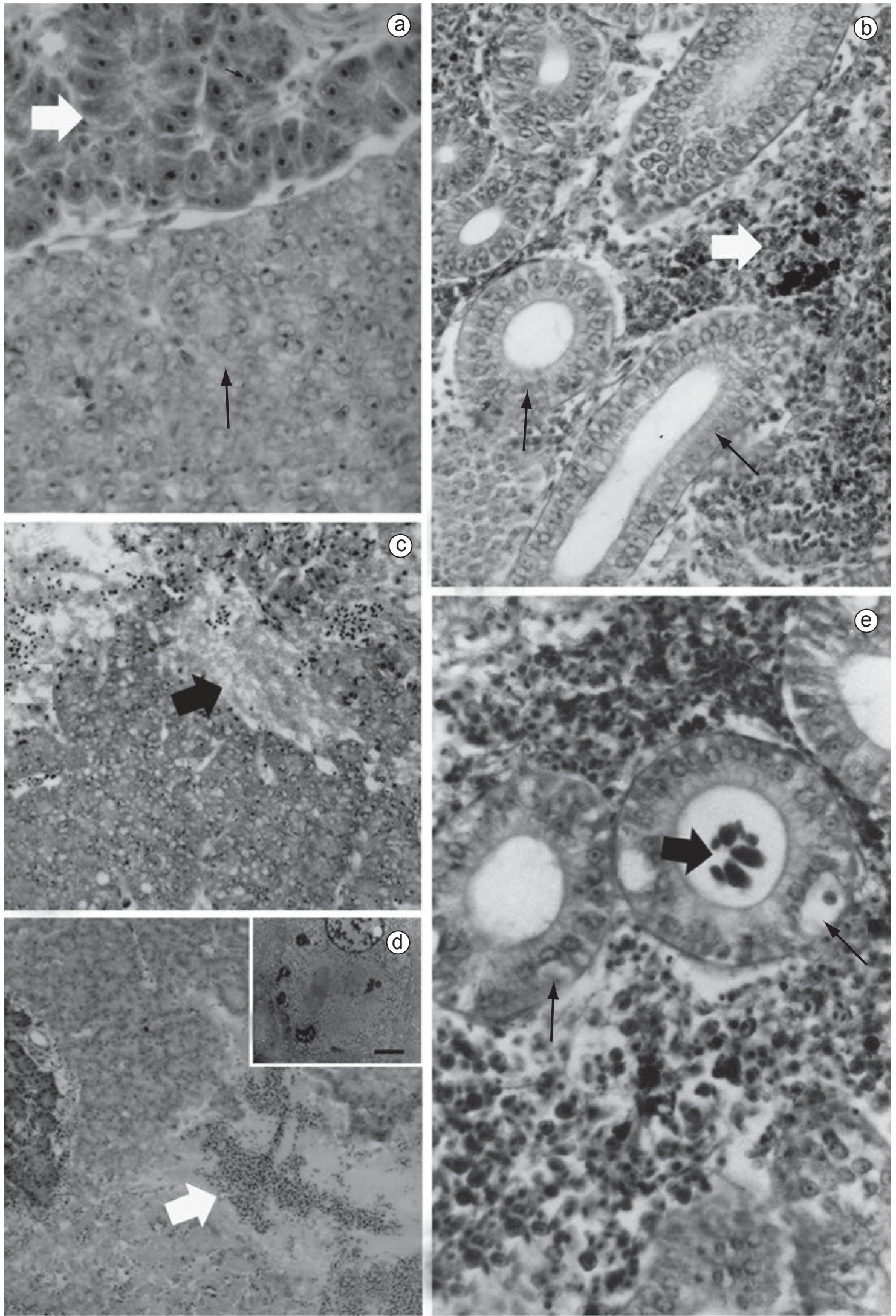

Figure 2 - Cross section of liver and posterior kidney of Hippoglossoides platessoides after TBT and DBT exposure. a) Liver from control group. The white and black arrows represent respectively the pancreatic and hepatic tissues. b) Posterior kidney from control group. Observe the renal parenchyma (white arrow) and ducts (black arrows). c) Liver from DBT eight doses group. The arrow shows a large necrosis area. d) Liver from TBT eight doses group.

Observe the necrosis area with red blood cells accumulation (arrow), and the necrotic cell ultrastructure in detail (d) (scale barr $=1 \mu \mathrm{m})$. e) Posterior kidney from TBT eight doses group. Observe the vacuolated cells in duct epithelial tissue (small arrows) and the cellular residues within the renal ducts (large arrow). A, B, C, D and E scale barr $=50 \mu \mathrm{m}$. 
levels. This, according to the authors, could be the possible explanation to the neurodegenerative effects observed in fish exposed to the organometals. On this way, the apoptosis or programmed cell death is an acceptable hypothesis to explain the lost of tissue function. Based on present results, we suggest both TBT and its metabolites like DBT are able to cause severe damages as necrosis associated with cell death as reported by Zhang et al. (2008).

TBT is a strong endocrine disruptor presenting various effects on fish sex differentiation. These damages are associated among others with the genotoxic role of TBT to aquatic organisms (Ferraro et al., 2004; Micael et al., 2007; Zhang et al., 2007). The damages in sinusoids as enlargement found after TBT and DBT exposures suggest a physiological response of the circulatory system or a consequence of the hormonal unbalance once TBT is a known endocrine disruptor agent (Matthiessen; Gibbs, 1998), or still an inflammatory response supported by the high occurrence of necrosis areas found in both target organs. Genetic modifications can also be interrelated as a source of cell death occurrence, mainly if associated with apoptosis (Filipak Neto et al., 2007). On this way the necrosis and evidences of apoptosis described here can be tentatively explained by both, the presence of reactive oxygen species and genotoxic damages. In addition, the physiological changes also found in this work such as the enlargement of vessels could be explained by the wide potential toxicity of TBT and metabolites as DBT.

The lesions found in both target organs suggest a cumulative and dose related effect when comparing both tested groups. The damages observed in individuals from the TBT water quality control group also indicate that TBT not ingested or released in feces can contaminate surrounding water and induce toxic effects to fish only exposed to draining water. As observed in the present results, DBT turns out to be as much or even more toxic than TBT in a different way that described by Daly, Fabris (1993); Halloran et al. (1998), but the mechanism is not elucidated yet (Oliveira Ribeiro et al., 2007). According to Guruge, Tanabe (2001), higher concentrations of organotins were observed in liver classifying this as a target organ and consequently more affected when exposed to this compound. The higher incidence of necrotic areas in liver and posterior kidney in individuals from the longer chronic exposure showed that the TBT or metabolites residual time is important to establish the lesion severity. Cellular apoptosis as described by Funahashi et al. (1980) is one of the most evident effects of organotin exposure. Although this kind of cell death has not been morphologically observed in the current work, the presence of cellular deposits within kidney ducts in all tested groups suggest the occurrence of this cell death as described by Alberts et al. (2005).

The incidence of vacuolated cells in epithelial tissue from ducts present in posterior kidney after eight doses in individuals exposed to DBT certainly is an indicative of osmoregulation or metabolism disturbances. This lesion was more evident after eight doses in individuals exposed to DBT confirming the toxic potential of this organotin form as described by Oliveira Ribeiro et al. (2007).
Overall, our results showed that histotoxicity of both TBT and DBT increases with time and even DBT appeared more toxic than TBT for $H$. platessoides. The potential toxicity of TBT to aquatic organisms and the risk to human population was recently very well documented by Rudel et al. (2007) in fish species. Due to the lack of information, new concerns about TBT metabolites have to be addressed and further studies must be encouraged and motivated to elucidate the associated toxic mechanisms. In addition, it is very important also to consider the effects of TBT and metabolites as part of complex mixtures of pollutants, to gain a more realistic interpretation despite of the myriad of possibilities and difficulties. Our further objectives are to study the effects of TBT and metabolites associated with other organic and inorganic chemicals in hepathocytes of fish after in vitro exposure.

Acknowledgments - The authors thank the CAPES (Brazilian Agency for Science and Technology), INRS (Institut National de la Recherce Scientifique - Canada) and Université du Québec à Rimouski (Québec) for financial support; and the Center of Electron Microscopy of Federal University of Paraná for technical assistance.

\section{REFERENCES}

ALBERTS, B., BRAY, D., LEWIS, J., MARTIN, R., ROBERTS, K. \& WATSON, J. D., 2005. Molecular Biology of the Cell, Garland Publishing, Inc, New York, $4^{\mathrm{a}}$ ed., 1463p.

ALZIEU, C. I., SANJUAN, J., MICHEL, P., BOREL, M. \& DRENO, J. P., 1989, Monitoring and assessment of butyltins in Atlantic coastal waters. Mar. Pollut. Bull., 20: 22-26.

BOORMAN, G. A., BOTTS, S., BUNTON, T. E., FOURNIE, J. W., HARSHBARGER, J. C., HAWKINS, W. E., HINTON, D. E., JOKINEN, M. P., OKIHIRO, M. S. \& WOLFE, M. J., 1997, Diagnostic criteria for degenerative, inflammatory, proliferative non-neoplastic and neoplastic liver lesions in medaka (Oryzias latipes): consensus of a national toxicology program pathology working group. Toxicol. Pathol., 25: 202-210.

BYRNE, P., SPEARE, D. \& FERGUSON, H. W., 1989, Effects of a cationic detergent on the gills and blood chemistry of rainbow trout Salmo gairdneri. Dis. Aquat. Org., 6: 195-196.

DALY, H. \& FABRIS, G., 1993, An environmental study of tributyltin in Victorian waters. Report to the State Government of Victoria Environmental Protection Authority.

ELLIS, D. V. \& PATTISINA, A., 1990, Widespread neogastropod imposex: a biological indicator of global TBT contamination. Mar. Pollut. Bull., 21: 248-253.

FENT, K., 1996, Ecotoxicology of organotin compounds. Crit. Rev. Toxicol., 26: 3-117.

FERRARO, M.V.M., FENOCCHIO, A.S., MANTOVANI, M.S., OLIVEIRA RIBEIRO, C.A. \& CESTARI, M.M., 2004. Mutagenic effects of tributyltin and inorganic lead ( $\mathrm{Pb}$ II) on the fish $H$. malabaricus as evaluated using the comet assay and the piscine micronucleus and chromosome aberration tests. Genet. Mol. Biol., 27: 103-7.

FILIPAK NETO, F., ZANATA, S.M., SILVA DE ASSIS, H.C., BUSSOLARO, D., FERRARO, M.V.M., RANDI, M.A.F., ALVES COSTA, J.R.M., CESTARI, M.M., ROCHE, H. \& OLIVEIRA RIBEIRO, C.A., 2007. Use of hepatocytes from Hoplias malabaricus to characterize the toxicity of a complex 
mixture of lipophilic halogenated compounds. Toxicol. In Vitro, 21: 706-715.

FISHBASE， 2008， http://www.fishbase.org/Summary/Species Summary.php?id=4239.

FUNAHASHI, N., IWASAKI, I. \& IDE, G., 1980, Effects of bis (tri-n-butyltin) oxide on endocrine and lymphoid organs of male rats. Acta Pathol. Jpn., 30: 955-966.

GIBBS, P. E., PASCOE, P. L. \& BURT, G. R., 1988, Sex change in the female dog-whelk, Nucella lapillus, induced by tributyltin from antifouling paint. J. Mar. Biol. Assoc., 68: 715-731.

GURUGE, K. S. \& TANABE, S., 2001, Contamination by persistent organochlorines and butyltin compounds in the West Coast of Sri Lanka. Mar. Pollut. Bull., 42: 179-186.

HALLORAN, K. O., AHOKAS, J. T. \& WRIGHT, P. F. A., 1998, Response of fish immune cells to in vitro organotin exposures. Aquat. Toxicol., 40: 141-156.

IMO Anti-Fouling Systems. International Convention on the Control of Harmful Anti-Fouling Systems on Ships. 2005 edition. London, IMO, 2005. Sales numbers: IA680E, ISBN 92-801-4195-3

INTERNATIONAL MARINE COATINGS, 2008, http://www. intersmoothspc.com/news/news_items/Regulation.pdf.

KINGTONG, S., CHITRAMVONG, Y. \& JANVILISRI, T., 2007, ATP-binding cassette multidrug transporters in Indianrock oyster Saccostrea forskali and their role in the export of an environmental organic pollutant tributyltin. Aquat. Toxicol., 85: 124-132.

LEE, R. F., 1991, Metabolism of tributyltin by marine animals and possible linkages to effects. Mar. Environ. Res., 32:29-35.

MARTIN, R. C., DIXON, D. G., MAGUIRE, R. J., HODSON, P. V. \& TKACZ, R. J., 1989, Acute toxicity, uptake, depuration and tissue distribution of tri-n-butyltin in rainbow trout, Salmo gairdneri. Aquat. Toxicol., 15: 37-52.

MATTHIESSEN, P. \& GIBBS, P. E., 1998, Critical appraisal of the evidence for tributyltin-mediated endocrine disruption in mollusks. Environ. Toxicol. Chem., 17: 37-43.

MICAEL, J., REIS-HENRIQUES, M.A., CARVALHO, A.P. \& SANTOS, M.M., 2007. Genotoxic effects of binary mixtures of xenoandrogens (tributyltin, triphenyltin) and a xenoestrogen (ethinylestradiol) in a partial life-cycle test with zebrafish (Danio rerio). Environ. Internat., 33:1035-1039.

OLIVEIRARIBEIRO, C.A.,PADRÓS, J., VALDEZDOMINGOS, F. X., AKAISHI, F. M. \& PELLETIER, É., 2007, Histopathological evidence of antagonistic effects of tributyltin on benzo[a]pyrene toxicity in the Arctic charr (Salvelinus alpinus). Sci. Total Environ., 372: 549-553.

OLIVEIRA RIBEIRO, C. A., PELLETIER, E. \& ROULEAU, C., 2000, Comparative gill damages and bioaccumulation of inorganic mercury on tropical and nordic fish. Environ. Res., 83: 286-292.
OLIVEIRA RIBEIRO, C. A., ROULEAU, C., PELLETIER, É., AUDET, C. \& TJALVE, H., 1999, Distribution kinetics of dietary methylmercury in the arctic charr (Salvelinus alpinus). Environ, Sci, Technol., 33: 902-907.

OLIVEIRA RIBEIRO, C. A., VOLLAIRE, Y., SANCHEZCHARDI, A. \& ROCHE, H., 2005, Bioaccumulation and the effects of organochlorine pesticides, PAH and heavy metals in the Eel (Anguilla anguilla) at the Camargue Nature Reserve, France. Aquat. Toxicol., 74: 53-69.

PICKSTON, L., 1988, Review of the use of antifoulants containing triorganotins in New Zealand. Report to the Ministry for the Environment, New Zealand.

RUDEL, H., MULLER, J., STEINHANSES, J. \& SCHROTERKERMANI, C., 2007. Retrospective monitoring of organotin compounds in freshwater fish from 1988 to 2003: results from the German environmental specimen bank. Chemosphere, 66:18841894.

SCHWAIGER, J., BUCHER, F., FERLING, H., KALBFUS, W. \& NEGELE, R. D., 1992, A prolonged toxicity study on the effects of sublethal concentrations of bis (tri-n-butyltin) oxide (TBTO): histopathological and histochemical findings in rainbow trout (Oncorhynchus myskiss). Aquat. Toxicol., 23: 31-48.

ST-JEAN, S.D., PELLETIER, E. \& COURTENAY, S.C., 2002, Very low levels of waterborne butyltins modulate hemocyte function in the blue mussel Mytilus edulis. Mar. Ecol. Prog. Ser. 236:155-161.

TANABE, S., IWATA, H. \& TATSUKAWA, R., 1994, Global contamination by persistent organochlorines residues in harbours and their ecotoxicological impact on marine mammals. Sci. Total Environ., 154: 163-177.

VALDEZ DOMINGOS, F. X., AZEVEDO, M., SILVA, M. D., RANDI, M. A. F., FREIRE, C. A., SILVA DE ASSIS, H. C. \& OLIVEIRA RIBEIRO, C. A., 2007, Multibiomarker assessment of three Brazilian estuaries using oysters as bioindicators. Environ. Res., 105: 350-363.

VIGLINO, L., PELLETIER, É. \& LEE, L. E. J., 2005, Butyltin species in benthic and pelagic organisms of the Saguenay Fjord (Canada) and imposex occurrence in common whelk (Buccinum undatum). Arch. Environ. Contam. Toxicol., 49: 1-17.

WESTER, P.W. \& CANTON, J.H., 1987. Histopathological study of Poecilia reticulate (guppy) after long-term exposure to bis(trin-butyltin)oxide (TBTO) and di-n-butyltindichloride (DBTC). Aquat. Toxicol., 10: 143-65.

ZHANG, J., ZUO, Z., CHEN, R., CHEN, Y. \& WANG, C., 2008. Tributyltin exposure causes brain damage in Sebastiscus marmoratus. Chemosphere, 73:337-343.

ZHANG, J., ZUO, Z., CHEN, Y., ZHAO, Y., HU, S. \& WANG, C., 2007. Effect of tributyltin on the development of ovary in female cuvier (Sebastiscus marmoratus). Aquat. Toxicol., 83:174-179. 